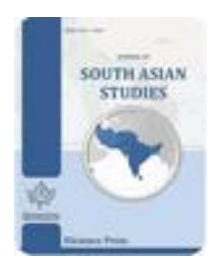

Available Online at EScience Press

Journal of South Asian Studies

ISSN: 2307-4000 (Online), 2308-7846 (Print)

https://esciencepress.net/journals/JSAS

\title{
The Ethnic Dilemma in Balochistan with More Focusing Upon Intra-Provincial Conflicts under CPEC Scenario
}

aMuhammad Akram Zaheer, bMuhammad Asim

a Informatics Group of Colleges, Arifwala, Punjab, Pakistan.

b Govt. Associate College (Boys), Rawalpindi Cantonment, Rawalpindi, Pakistan.

*Corresponding Author Email ID: akramzaheer86@yahoo.com

\section{A B S T R A C T}

Balochistan exists in a state of conflict since the partition but, initially, the nature of the conflict was based upon the future of princely states that led to the insurgency against the federation of Pakistan in 1948, 1958, and 1963. After the emergence of Balochistan as a full province, the nature of conflict shifted towards Baloch ethnic nationalism that directed insurgencies during 1973 and 2004. The government of Pakistan claims that all the waves of insurgencies have huge foreign funding by rival states. While the concerns of major powers on re-constructing Kasghar-Gwadar Road plan 2004 (renamed as China-Pakistan Economic Corridor [CPEC] in 2013) triggered Baloch ethnic nationalism and already existed intra-provincial conflicts once again that led Pashtun-Brahui, Brahui-Baloch, and Baloch-Pashtun differences. However, a detailed briefing by Chinese Ambassador Zhao Lijian has undermined all the concerns of ethnic communities in entire Pakistan including Balochistan. However, there are still some voices for insecurity and predicted economic deprivation in the province. This study tries to describe the history of ethnic dilemma in Balochistan along with demographic structure, CPEC related projects in the province, and the rival states' nexus for triggering ethnonational separatism and intra-provincial conflicts against Pakistan. While the issue is rising by Baloch nationalists regarding preferring the eastern, western, or central route of CPEC is being discussed in the last.

Keywords: Dar-ul-Umara, Brahui, Lanzhou-Xinjiang Railway, Seestan-o-Baluchestan, Washuk.

\section{INTRODUCTION}

Since the 1947, Pakistan comprises of ethnically diverse areas. During the first 1951 census of Pakistan, this divergence highlighted very significantly. As federation of Pakistan was consisted upon four provinces (Punjab, NWFP, Sindh and East Bengal), 13 princely states (Bahawalpur, Khairpur, Chitral, Swat, Hunza, Nagar, Amb, Phulra, Dir, Lasbela, Kharan, Makran and Khanate of Kalat), one chief commissioner's province (Balochistan) and tribal areas, the table given below describes the population ratio and existing areas of different ethnic communities within the federation of Pakistan. [See Table no. 1]

Because of such blend of ethnic communities, centerprovinces or center-states conflicts had been generated since the formation of Pakistan. The first example of these conflicts was the to recognize Urdu as a national language instead of both; Urdu and Bengali while, the second example was the merger of princely states into the federation of Pakistan; especially the issue about Khanate of Kalat. Although, there were lot of intraprovincial conflicts but those were not so triggered like center-provinces or center-states conflicts.

\section{HISTORY OF ETHNIC DILEMMA IN BALOCHISTAN}

As the current territory of Balochistan consisted upon four princely states (Kharan, Makran, Lasbela and Kalat), one Chief Commisioner's Province (Balochistan), Baloch tribes and the territory of Gwadar (under the Sultanate of Muscat and Oman) at the time of partition, States of Kharan, Lasbela and Makran showed their open willingness to join federation of Pakistan (Rodeni, 1997). On the other hand, there are two groups of historians 
that describe the post-partition politics of Kalat State / Khanate in two different aspects. Anti-Pakistan Baloch nationalists like Waseem Altaf claim that the Khanate of Kalat under Ahmed Yaar Khan decided to get sovereign status according to the options given by the British Prime Minister Clement Attlee (1945-1951) to all the princely states at that time (Altaf, 2017; Siddiqi, 2012). While Pakistan installed its army there in April 1948 which forced Khan of Kalat to accede the state to Pakistan. In reaction, his brother Prince Kareem Khan called for independence of the Kalat and departed to Afghanistan regarding seeking aid for beginning an armed struggle against Pakistan but failed. This occupation led the annexation of entire Balochistan to Pakistan till the June 1948 (Akbar, 2011).

Table 1. Demographic Structure of Pakistan according to Census 1951.

\begin{tabular}{lcl}
\hline \multicolumn{1}{c}{ Linguistic Community } & $\begin{array}{c}\text { Population } \\
\text { Ratio }\end{array}$ & \multicolumn{1}{c}{ Areas } \\
\hline Bengali & $53.6 \%$ & East Bengal Provnice and some areas of Karachi \\
\hline Punjabi (including Saraiki) & $27.5 \%$ & Punjab Province and Bahawalpur State \\
\hline Urdu & $5.3 \%$ & Entire Country but majority in Karachi and Hyderabad \\
\hline Sindhi & $5.5 \%$ & Sindh Province, Khairpur State and some parts of Lasbela State \\
\hline Pashto & $4.7 \%$ & $\begin{array}{l}\text { Northwest Frontier Province, Swat State, Amb State, Phulra State, } \\
\text { Dir State, northeast parts of Ceif Commissioner's Province of } \\
\text { Balochistan and tribal areas. }\end{array}$ \\
\hline Balochi (including Brahui and & $1.5 \%$ & $\begin{array}{l}\text { Chief Commissionors Province of Balochistan (except northeastern } \\
\text { parts), Kharan State, Makran State, Khanate of Kalat and some } \\
\text { parts of Lasbela State }\end{array}$ \\
\hline Others & & $\begin{array}{l}\text { Chitral State, Hunza State, Nagar State, other parts of northern } \\
\text { areas and Kashmir }\end{array}$ \\
\hline
\end{tabular}

Source: (PBS, 2019).

On the other hand, pro-Pakistani historians like Yogeena Veena argue that the discussions between the Government of Pakistan and the State of Kalat were started in February 1948 (Baloch, 2017; Veena, 2015).

Jinnah wrote a letter to the Khan of Kalat.

"I advise you to join Pakistan without further delay, and, let me have your final reply which you promised to do after your stay with me in Karachi when we fully discussed the whole question in all its aspects" (Baloch, 2017; Veena, 2015).

Similarly, Jinnah visited Sibi on February 15, 1948. Main reason for this visit of Jinnah was also to convince the Khan of Kalat regarding acceding to Pakistan (Saiyid, 2012). However, Khan of Kalat could not meet him because of illness. So, he wrote the letter to Jinnah that he had summoned both Houses of the Kalat's Parliament; Dar-ul-Awam and Dar-ul-Umara for their decision about the future relations with the Dominion of Pakistan, and he will inform him about the decision of Parliament by the end of this month (Saiyid, 2012).
On February 21, 1948, Kalat's Dar-ul-Awam decided not to accede Pakistan but to initiate a treaty regarding determining future relations with Pakistan. This decision led Ministry of Foreign Affairs in Pakistan to make a law regarding annexation of princely states with Pakistan on March 17, 1948. With following this law, Khan of Kalat signed unconditional agreement about annexation of the state to Pakistan on March 27, 1948 (Akbar, 2011; Siddiqi, 2012).

Since then, the history of Balochistan got two dimensions. One reflects anti-Pakistan attitude while, second describes pro-Pakistani viewpoint. On the other hand, US Ambassador to Pakistan at that time informed Secretary of State in his dispatch on March 23, 1948, that "Kharan, Makran and Lasbela (feudatory states of Kalat) had joined Pakistan" (Veena, 2015). This dispatch also supported pro-Pakistani viewpoint in this regard. According to Yaqoob Khan Bangash, Khan of Kalat coerced to join Pakistan on March 27, 1948, when his efforts to acquire sovereign Balochistan became failed. Unconditional annexation of Makran, Kharan and 
Lasbela to Pakistan left the Khan of Kalat alone in his ambitions (Bangash, 2011). So, he took decision against his own parliament and announced annexation of Kalat with Pakistan. However, some anti-Pakistan Baloch nationalists including his brother started agitation against the federation of Pakistan with foreign funding that became fail by the efforts of pro-Pakistani populace, federal government and Pakistan Army (Bangash, 2011; Akbar, 2011).

The next 1958-1959 agitation was initiated by Nawab Nauroz Khan (head of Zarakzai tribe in the Khanate of Kalat). Because of his self-assumptions about undermining tribal status and state / khanate structure, he took up arms with his followers against the One Unit policy. This insurgency was bottled-up by Pakistan Army because of highly proved Indian and Afghan military intelligence support (Balochistan Tumult, 2012). Majority of militants were arrested and charged with treason. Five of Nauroz Khan's family members were later hanged upon the charges of treason in Hyderabad Jail. Nawab Nauroz Khan was also died in imprisonment (Baloch, 2008, Bangash, 2011; Akbar, 2011).

To observe the worst failure of the statehood-crusted militancy in the province, rival state encouraged Baloch nationalists in 1963 to stand against the federation of Pakistan on the self-crafted issue of inappropriate share of Balochistan in the revenue generated from the Sui Gas Fields (Said, 1994; Ahmad, 1992). Apparently, this insurgency was leading by the prominent Mengal, Marri and Bugti tribal leaders that demanding tribal-based share of Balochistan in the revenue but actually, it was another effort to destabilize federation of Pakistan and destruct its military power. Insurgents blasted ambushed convoys and railway tracks. A Marxistoriented Sher Muhammad Marri (head of Marri tribe) led this insurgency with the open support of Afghanistan and Soviet Union. However, Pakistan Army reacted by destroying big portion of the Marri tribe's land that forced majority of militants to leave anti-state activities. But their little segment continued agitation against the federation till the 1967 (Said, 1994, P.436, Ahmad, 1992, P.176). General amnesty awarded by the federation of Pakistan on humanitarian bases to the Baloch militants in 1967 regarding leaving foreign sponsored militant attitude facilitated this segment to throw their weapons. Several reports also claimed with referring intelligence reports of KGB, RAW and KHAD that the actual purpose of funding this insurgency was to cut off Pakistan's nuclear program at initial level somewhere at "secret place" in Balochistan (Harrison, 1981, P.72). On the other hand, federal elites revised their "One Unit" policy in 1970 and established entire Balochistan region as one province under the federation of Pakistan with merging four princely states, Chief Commissioner's Balochistan, territory of Gwadar, and tribal Balochistan. Unlike elimination, this decision caused conversion of princely states or tribal based insurgency into province-based insurgency. In fact, anti-Pakistan trends of rival states had also been changed after analyzing counter strategy of Pakistan. Thus, to secure their interests in the region, now they were propagating a sovereign Balochistan on the base of Baloch ethnic nationalism (Harrison, 1981; Said, 1994; Ahmad, 1992).

Now, Soviet Union including USSR-backed Iraq planned to destabilize Pakistan and Iran mutually by installing sentiments for "Greater Balochistan" in Pakistani and Iranian Balochistan. This plan became failed through the military raid on the Iraqi Embassy in Islamabad in 1973 where huge volume of Soviet-smuggled weapons was searched out (Nunan, 2016; John, 2009). With citing treason, President Zulfaqar Ali Bhutto dismissed provincial assemblies of Balochistan and Northwest frontier Province, and, imposed martial law in both provinces regarding investigating secret relations between political leaders of both provinces with Soviet Union and Iraq. However, some Baloch nationalists including Marxist-Leninist-oriented Khair Bakhsh Marri called this dismissal as violation of Balochistan's political rights, led guerrilla war against federation of Pakistan that resulted 300 to 400 causalities of Pakistan Army while, 7,300 to 9,000 separatists were killed till the 1977 (Nunan, 2016; John, 2009). With the assistance of Imperial Iranian Army, this insurgency was not only crushed but also forced anti-Pakistan Baloch nationalists to either leave the country or accept federal structure. While the general amnesty granted by the Lieutenant General Rahimudin Khan in 1977 under the martial law also facilitated Baloch militants to give up foreign funded anti-state activities (Nunan, 2016; John, 2009).

At the completely end of this insurgency, Pakistan designed a counter strategy to hide the Balochistan and its hot-watered deep sea from rival eyes. On backing Afghan Jehad, indirectly Pakistan designed a successful multifarious web against India, Afghanistan and Soviet Union nexus which kept them away from Balochistan but wiped out KHAD-RAW ties from Kabul against 
Pakistan till the 1996 (Haque, 2020). However, PostTaliban Afghanistan once again encourages India and other rival states to station their agents around the Durand Line regarding detracting proposed KashgarGwadar Road link through NWFP and Balochistan. As the present form of CPEC project was firstly projected by the General Pervez Musharraf, Chinese engineers with the collaboration of National Highway Authority completed Khunjerab-Gilgit part of Karakoram Highway as metal road during his regime. However, strong foreign funded militancy in NWFP and Balochistan against this project coerced him to postpone further developments until the successful military operation against anti-Pakistan elements. In 2004, militants attacked Gwadar port that resulted death of three Chinese engineers and four wounded. In reaction, Pakistan Army initiated a largescale operation in Balochistan, NWFP and Tribal Areas against anti-state sponsored elements. In the meanwhile, Baloch political leaders; Nawab Akbar Bugti and Balach Marri offered a 15-points agenda to the federal government of Pakistan that ultimately aimed to demand greater regional autonomy to the province over its resources, and removing military bases from the province (Shaukat, 2016). On the other hand, military intelligence reports were indicating huge foreign funding behind these demands. On December 15, 2005, the inspector general of the Frontier Corps; Major General Shujaat Zamir Dar including his deputy Brigadier Salim Nawaz were wounded after firing at their helicopter in the Balochistan. Chain of this attack was also proved with the 15-points agenda and Gwadar Port Attack 2004 that forced Pakistan Army to launch military operation against sponsored Baloch nationalists. Furthermore, an interview of Nawab Akbar
Bugti to BBC regarding demanding military support from India for independence of Balochistan made the situation more intense (Akbar, 2017). On August 26, 2006, He was killed in a military operation along with 37 militants and 21 soldiers of Pakistan Amry (Akbar, 2017). Anti-Pakistan elements tried to cash this operation as an attack on Baloch ethnic identity and motivated common Baloch people to start agitation against federation of Pakistan. However, Pakistan Army not only crush this insurgency but exposed hidden ambitions of India, Afghanistan and other rival states behind sponsoring Baloch ethnic identity-based militancy. One of such ambitions was to curtail CPEC Project while, other one was to trace out secret military reservoirs in the province (Shafqat, 2017).

Since then, Balochistan is suffering from two kinds of ethnic conflicts. One is based on Baloch ethnic nationalism and second is intra-provincial ethnic conflicts. Besides historical existence of both conflicts, Government of Pakistan claims that both conflicts are triggering by the rival states regarding destabilizing Pakistan and disturbing CPEC project. Therefore, to analyze both conflicts, firstly this study has to examine demographic structure of Balochistan and then ethnic irritants under CPEC scenario.

\section{DEMOGRAPHIC STRUCTURE OF BALOCHISTAN}

Since 1998, demographic structure has been varied a lot. Several surveys indicated different percentage of ethnolinguistic groups in Balochistan than the 1998 census. So, the table given below is trying to measure appropriate figures about existing population of different ethno-linguistic groups in entire Balochistan through statistical formulas.

Table 2. Average Population of Ethno-Linguistic Groups in Balochistan.

\begin{tabular}{cccccccccc}
\hline Languages & Balochi & Pashto & Brahui & Urdu & Sindhi & Saraiki & Punjabi & $\begin{array}{c}\text { Persian } \\
\text { (Hazargi) }\end{array}$ & Others \\
\hline Percentage & $44 \%$ & $29.6 \%$ & $13 \%$ & $2.5 \%$ & $5.6 \%$ & $02 \%$ & $2.4 \%$ & $0.5 \%$ & $0.4 \%$ \\
\hline
\end{tabular}

Source: (Census of 1998, 1998, Percentage Distribution of Households by Language Usually Spoken and Region/Province - 1998 Census, 2017).

This table highlights three major ethno-linguistic groups in Balochistan; Balochi, Pashtoon and Brahui. As there are 22 districts of Balochistan, Quetta is the metropolitian city, having mixed demographic structure while Urdu and Punjabi speaking people have also been settled in scatter form in entire province (Census of 1998, 1998, Lakiwal, 2017). However, the district wise existance of other ethno-linguistic groups is being presented in the table no. 3 given below. 
Table 3. Districts wise Presence of Ethno-Linguistic Groups in Balochistan.

\begin{tabular}{cl}
\hline Language & \multicolumn{1}{c}{ Districts } \\
\hline Balochi & $\begin{array}{l}\text { Gwadar, Lasbela, Awaran, Kech (Turbet), Punjgur, Kharan, Washuk, Khuzdar, Chagai, Nushki, } \\
\text { Jafarabad, Jhal Magsi, Nasirabad, Bolan, Dera Bugti, Kohlu, Harnai and Sibi }\end{array}$ \\
\hline Pashto & Zhob, Pishin, Loralai, Qila Abdullah, Qila Saifullah, Sherani and Ziarat \\
\hline Brahui & Khuzdar, Mastung and Kalat \\
\hline Sindhi & Jafarabad and Lasbela \\
\hline Saraiki & Musa Khel and Barkhan \\
\hline Persian & Iran-Afghanistan border area of Chagai, and Hazara town in Quetta \\
(Hazargi) &
\end{tabular}

Source: (Census of 1998, 1998; Lakiwal, 2017).

\section{ETHNIC IRRITANTS UNDER CPEC SCENARIO}

As Government of Pakistan claims that anti-Pakistan elements are funding to promote both; the Baloch ethnic nationalism and the intra-province conflicts between different ethnic segments like Pashtun and Brahui, Pashtun and Baloch, and Baloch and Brahui, it is analyzed that both types of conflicts got foreign back during proposal of Kashgar-Gwadar Road reconstruction in 2004 but it was highly triggered after the killing of Akbar Bugti (Rafiq, 2017).

In 2008, Pervez Musharraf stepped down because of political instability (Shah, 2008). To see his step down, the ethnic diversity further triggered by the rival states. On August 12, 2009, Khan of Kalat Mir Suleman Dawood declared himself as the ruler of Greater Balochistan (Baloch, 2009). He also announced a so-called legislative council of Independent Greater Balochistan. This council claimed a domain that includes Pakistani Balochistan and Iranian Seestan-o-Baluchestan; However, it did not include Afghan Baloch regions. From the platform of this council, Mir Suleman Dawood stated that the "UK had a moral responsibility to raise the issue of Balochistan's illegal occupation at international level" (Baloch, 2009). However, this declaration could not gain any minor support at the grass root level in Pakistan or Iran. So, this funded claim flew in the air (Bhai, 2009).

On the other hand, the government of Pakistan People's Party once again announced to restart Musharraf's planned project on May 22, 2013. President Asif Ali Zardari and the Chinese Premier Li Keqiang agreed to construct an economic corridor between both countries (Fels, 2016). Both sides also determined to further boost mutual connectivity regarding long term planning under China-Pakistan Economic Corridor. Moreover, threedimensional role of President Asif Ali Zardari positively changed the ethnic and economic environment of Balochistan. At one side, he projected himself as belong to Sindhi language speaking Baloch tribe and a true wellwisher of Baloch ethnic community while, at second side, he convinced Chinese leadership on the base of common democratic-socialist ideology that would contribute to future reading securing mutual regional political and economic interests of both nations. Similarly, his third dimension was not to stop military operation against anti-Pakistan Baloch nationalists even he inaugurated several welfare-based projects for Balochistan like Aghaz Haqooq-e-Balochistan Package (Fels, 2016, PP.484-486).

His presidency caused not only an elimination of remaining little Baloch ethnic nationalism and undermining intra-provincial conflicts through democratic channel but also made closer China and Iran to Pakistan on an issue of regional security and common interests. Similarly, he had convinced Afghanistan to participate in the CPEC Project (Khan, 2016). He also exposed Indian-funded militancy in Balochistan worldwide. During NAM summit in Sharm-ul-Sheikh, Prime Minister Yousaf Raza Gilani handed over the proofs of Indian involvement not only to Indian Prime Minister Manmohan Singh but also to UN Secretary General Ban Ki-moon and other participants from 120 member states (Gilani, 2009). However, regional politics changed during the succeeding government of Pakistan Muslim League (Nawaz). Although, sponsored militancy including funded Baloch ethnic nationalism in the Balochistan went down to a lowest level, but Iranian and Afghan attitudes molded towards Indian hegemonic orientations. Indian funded road from Kabul to Chabahar and Modi's speeches during his visit to Central Asian states regarding urging them to use Chabahar Port 
instead of shortest-routed Gwadar Port attracted Iranian economic interests that were going to be damaged in case of CPEC Project completion (Mukherjee, 2016). However, issue of arresting Indian spy Kalbhoshan Yadev and tracing out its Chabahar based anti-Pakistan campaign put pressure on Iranian government from Pakistan and China regarding either to declare its antiPakistan position or participate in CPEC Project (Siddiq, 2016). Thus, with realizing future demise of Chabahar Port in case of Gwadar Port functioning, Iran showed its intention to participate in CPEC Project. Because it would be the only solution of somewhat business sustaining opportunity for Chabahar Port. For this purpose, Iran admitted the statement issued by Chief Minister of Balochistan; Sanaullah Zahri on January 12, 2016, that Chabahar and Gwadar are "Sister Port Cities" (Zafar, 2016).

On the other hand, intra-provincial conflicts were also be managed during Pakistan People's Party regime when the provincial government of PPP added all the ethnic segments in the provincial government. However, ethnic management issues were again raised after 2010 when Devolution Plan of Pervez Musharraf became expire (Hashemi, 2015).

\section{Ethnic Management Issue}

According to different political analysts like Shehzad Arif, Ritu Nayyar-Stone, Andrew Golda and William Cartier, Devolution Plan of Pervez Musharraf in Pakistan considers as the best example for managing ethnic issues (Arif, Cartier, Golda, \& Nayyar-Stone, 2017; Hashemi, 2015). His non-political parties base Devolution Plan generated harmonious environment in entire country. At each district, tehsil or town level, groups of the candidates for local constituencies were comprised of the people from different castes, races and languages. Similarly, this system reduced the powers of provincial assemblies, and empowered district, tehsil and town councils that further abridged dependency upon provincial elites but also overcame intra-provincial conflicts in entire country (Arif, Cartier, Golda, \& NayyarStone, 2017). Since 2000 to 2010, this system successfully delivered socio-political and economic rights to the people of Pakistan without any political, linguistic, racial or any other social differences (Arif, Cartier, Golda, \& Nayyar-Stone, 2017). However, article 140 (a) under the $18^{\text {th }}$ amendment in the Constitution of 1973 describes that "Each Province shall, by law, establish a local government system and devolve political, administrative, and financial responsibility and authority to the elected representatives of the local governments" (18th Amendment, 2010). While the clause 02 of this article directs that "the Election Commission of Pakistan will organize the election of Local Government". (18th Amendment, 2010)

Besides provincial elites of other provinces, politicians in the Balochistan had very much socialized by the Devolution Plan 2001, and, they had realized about the worth of local government system (Rolls, 2008). Therefore, provincial assembly of Balochistan passed the Local Government Act soon after the passing of $18^{\text {th }}$ amendment in 2010 while; other provinces legislated in 2013 for same purpose (Kakar, 2017). Like Devolution Plan 2001, duration of local government also continued for four years in Balochistan under this act. However, like other provincial assemblies, Balochistan Assembly also ratified local government elections on party basis. This decision negatively affected ethnic management under Devolution Plan (Rolls, 2008). Firstly, the members of provincial assembly supported party candidates in their constituencies. Secondly, because of open support by the provincial government to their favoring candidates, political rivals felt insure and faced several kinds of socio-political deprivations before and after the elections in entire province. This situation has once again triggered the ethno-linguistic, ethno-racial and ethno-caste differences (Rolls, 2008; Kakar, 2017). Similarly, according to the Local Government Act 2010 passed by the Balochistan Assembly, province (like other provinces) has established a Provincial Finance Commission (PFC) headed by the provincial finance minister. Apparently, its prime objective is to allocate fund for different projects to the local councils but actually, hidden purpose behind this legislation is to make local governments more limited regarding their political and economic functions (imposing taxes or other regulatory functions) and ensure them to be fully dependent upon provincial government (Rolls, 2008; Kakar, 2017). For Balochistan, this legislation proved as again harmful for restoring ethnic differences. Public representatives from Pashtun, Brahui and Hazara communities at local councils' level have considered their selves as totally dependent upon the Baloch provincial elites. So, they are still demanding more political and economic powers to local councils like Devolution Plan 2001 from both the Post-2013 Baloch- 
hegemonic regimes of Abdul Malik Baloch and the Sanaullah Zahri in Balochistan (Rolls, 2008; Kakar, 2017).

Another issue that restored ethno-linguistic differences after Pervez Musharraf regime was renaming Northwest Frontier Province to Khyber Pakhtunkhwa under $18^{\text {th }}$ amendment in the Constitution of 1973. This decision at one end, satisfying Pashtun ethnic community in the Northwest Frontier Province but at another end, it triggered ethno-linguistic identities in entire country including Balochistan (Daily Express Tribune, June 09, 2010). Like Hindko speaking Hazara community in Khyber Pakhtunkhwa, Saraiki speaking community in Punjab, and Urdu speaking community in Sindh, Pashto speaking community in Balochistan also demanded their separate province for securing its separate ethnolinguistic identity (Daily Express Tribune, June 09, 2010). According to the Senator Afrasiab Khattak, "South Khyber Pakhtunkhwa should be established for the Pashtun people of Balochistan while, tribal areas must be merged into Khyber Pakhtunkhwa" (Khattak, 2011). To avoid from such situation and to managing ethnic differences, several center-nationalist political parties like PML (Q) and PTI are demanding new provinces on administrative basis instead of highlighting any ethnic identity (The News, September 13, 2013; Aaj News, April 14, 2010).

To examine intra-provincial conflicts between Brahui, Pashtun and Baloch communities, firstly we have to look CPEC related projects in Balochistan.

\section{Cpec Related Projects in Balochistan}

On October 05, 2016, Chinese ambassador to Pakistan Zhao Lijian explained at least 16 CPEC related projects in Balochistan. These include Gwadar New International Airport, Gwadar Smart Port City, Hubco Coal Power Plant, 300MW Gwadar Power Plant, Gwadar Smart Port City Master Plan, Expansion of Multi-purpose Terminal including Gwadar-Nawabshah LNG Terminal and Pipeline, Gwadar Free Zone, Fresh Water Supply for Gwadar City, Treatment Plants for Gwadar City, Gwadar Hospital Upgradation, Breakwater \& Dredging Wastewater in Gwadar, Gwadar Primary School, and Gwadar Technical \& Vocational College (Lijian, 2016).

There are also some proposed roads that would link Balochistan to entire country and China. These are.

1) First road; called national Highway (N-30) will link Brahui majority district of Khuzdar to Balochi speaking tehsil of Basima in Washuk District which will further connect Pashtun areas of northeastern Balochistan (Lijian, 2016).

2) Second road; called National Highway (N-50) will connect Pashtun majority areas of Dera Ismail Khan to Quetta which further link Brahui speaking districts of Kalat and Baloch speaking areas of Gwadar, Lasbela, Awaran and Kech (Turbet) districts (Lijian, 2016).

3) Gwadar Eastbay Expressway I and Gwadar Eastbay Expressway II that will link Baloch majority area of Gwadar to Karachi via Makran Coastal Highway (N10) (Lijian, 2016).

Similarly, a proposed wide railway network would encourage socio-economic developments in entire Balochistan. To link Gwadar with Kashgar, there are three proposed railway tracks.

1) First railway line will be constructed from Baloch majority district of Gwadar to Karachi (Rafiq, 2017).

2) Second railway line will connect Baloch majority adistrict of Gwadar to Brahui majority tehsil of Spezand (District Mastung) and then District Jacobabad of Sindh Province. (Rafiq, 2017).

3) While the third railway line will connect Pashtun majority tehsil of Bostan in District Pishin to Saraiki speaking tehsil of Darya Khan in District Bhakkar (Rafiq, 2017).

Furthermore, these railway lines will be linked further to Kunjerab Railway (Taxila Junction to Khunjerab) via mainstream railway lines in Pakistan. Moreover, it will be associated with the Lanzhou-Xinjiang Railway of China for linking Urmuqi, Kashgar, Lanzhou and Gansu (Ahmad, 2014).

These projects and proposed railway stations would not only affect domestic economic activities in the major cities of Balochistan, but it would become a cause of modernization in the parochialism. It would further alter the ancient patterns of tribal, oldest-mountainous or culturally conservative lifestyle according to global patterns that can associate common Baloch people to the relatively developed population of Karachi, Lahore and Islamabad. Similarly, each proposed railway station or road interchange would encourage local and international investors to install their business around such places that link them to domestic as well as international market (Bukhari, 2016). 
Issue of Preferring Eastern, Western or Central Route of CPEC

After undermining anti-Pakistan funded Baloch ethnonational separatism and voices for regional autonomy, modern phase of intra-Balochistan conflict is now experiencing another triggered issue of preferring eastern, western or central route of CPEC. Different segments of Baloch and Pashtun politicians and nationalists like Dr. Abdul Malik Baloch, Asfandyar Wali and Afrasiyat Khattak are describing their concerns over construction of eastern, western or central route firstly. According to them, western route of CPEC must be constructed firstly because of predicting poverty alleviation from backward regions of Khyber Pakhtunkhwa and Balochistan without any ethnic discrimination while, they also blame on federal elites (belong to Punjab and Sindh) that they are highly preferring eastern route of this project that would only facilitate already developed Punjab and Sindh (Junaidi, 2016). Similarly, some Baloch nationalists like Mir Hasil Bizenjo and Sardar Akhtar Jaan Mengal blame that CPEC projects are just facilitating Pashtun and Brahui majority areas in Balochistan (Ghumman, 2015; Mengal, 2017). However, Chinese ambassador to Pakistan Zhao Lijian fully briefed chief ministers of Khyber Pakhtunkhwa and Balochistan on October 05, 2016 and satisfied them on preferred working over western route that would equally facilitate Pashtun, Brahui and Baloch ethnic communities in Balochistan. Same would be the case with central route for Balochistan while, eastern route would equally facilitate Punjabi, Saraiki, Sindhi and Urdu speaking communities in Punjab and Sindh along with Balochistan through Coastal Makran Highway from Karachi to Gwadar. Since then, such voices have also been minimized but a little bit element are still triggering against such satisfaction (Lijian, 2016; Bukhari, 2016; Rafiq, 2017).

\section{CONCLUSION}

There is no doubt that Balochistan like other provinces of Pakistan; is suffering from intra-provincial conflicts since 1947. Although, these conflicts were weak till the proposal of Pervez Musharraf in 2004 regarding reconstructing Kashgar-Gwadar Road but since then, they are raised a lot because of either economic deprivations or economic needs. Although, federal elites of Pakistan are continuously trying to resolve such issues, but this diversity can be triggered more in case of increasing already existed foreign funding by rival states. Similarly, major powers that have vast concerns over ChinaPakistan Economic Corridor; can also provoke Baloch ethnic nationalism and intra-provincial conflicts for the sake of their interests.

To analyze such fears and threats, several scholars and patriotic elements in Pakistan urge the federal government to design more provinces on administrative bases including restoring the status of Gwadar as federal administrative territory. According to Khalid Chandio and Dr. Niaz Murtaza, Balochistan should be divided into two provinces on the base of Baloch and Pashtun identities while Gwadar should be controlled under federal government (like Indian union states territories) (Chandio, 2015; Murtaza, 2014). On the other hand, Gallup Pakistan Survey indicated that 42 percent Pakistanis demand new provinces on administrative bases as compared to just 15 percent Pakistanis who favor linguistic base provinces (Rafay, 2012). Hence, it is summarized that new administrative base provinces and truly empowered local government system in entire Pakistan including Balochistan province would not only empower domestic population of different regions without any sense of socio-political or economic deprivation, but it would also undermine any sponsored or foreign-funded ethno-national separatism against unity of the nation. Economic prosperity and the sociopolitical development of the country is only concealed in the respective paradigm.

\section{REFERENCES}

18th Amendment. (2010). Islamabad: Parliament Secretariat.

Aaj News. (April 14, 2010). Retrieved from Aaj News: http://aaj.tv/2010/04/pml-q-for-creation-newprovinces/

Alamgir, A. (2013, August 11). Pakistan's Balochistan Problem: An Insurgency's Rebirth. Retrieved June 21, 2017, from Balochistan Point: http://thebalochistanpoint.com/pakistansbalochistan-problem-an-insurgencys-rebirth/

Altaf, W. (2017, July 26). Accession at Gunpoint. Retrieved from Eurasian Politics: https://eurasianpolitics.wordpress.com/2017/07 /26/accession-at-gunpoint/

Arif, S., Cartier, W., Golda, A., \& Nayyar-Stone, R. (2017). The Local Government System in Pakistan: Citizens Perceptions and Preferences. Washington: Urban 
Institute Center on International Development and Governance.

Butt, A. (2016, December 16). How the East was lost in 1971. Retrieved June 29, 2017, from DAWN: http://nation.com.pk/blogs/16-Dec-2016/howthe-east-was-lost

Census of 1998. (1998). Islamabad: Government of Pakistan.

Daily Express Tribune. (June 09, 2010). Islamabad: Express News.

Ghafoor, A. (2017, April 13). Tourism Activities In Swat On Peak This Year:MD PTDC. Retrieved from Pakistan Point: https://www.pakistanpoint.com/en/pakistan/ne ws/tourism-activities-in-swat-on-peak-this-year125999.html

Ghumman, K. (2015, May 29). Baloch-Pakhtun rivalry rears its head at CPEC meeting. Retrieved from DAWN: https://www.dawn.com/news/1184917

Gilani, Y. R. (2009, July 16). PM Gilani gives proof of Indian interference in Balochistan to Manmohan. Retrieved from Pak Tribune: http://paktribune.com/news/PM-Gilani-givesproof-of-Indian-interference-in-Balochistan-toManmohan-217099.html

Hashemi, R. S. (2015). Baloch Ethnicity: An Analysis of the Issue and Conflict with the State. Journal of the Research Society of Pakistan, 57-84.

Junaidi, I. (2016, January 21). Politicians express concerns over CPEC. Retrieved from DAWN: http://epaper.dawn.com/DetailImage.php?StoryI mage=21_01_2016_004_006

Kakar, A. (2017, March 16). Local government and Pakistan's reluctant political elite. Retrieved from London School of Economics: https://blogs.lse.ac.uk/southasia/2017/03/16/lo cal-governments-and-pakistans-reluctantpolitical-elite/

Khan, M. (2013). The Pashtunistan Concept: Does it have wider support in Pakhtunkhwa? Retrieved June 30, 2017, from The Peshawar.com: http://thepeshawar.com/thekhyber/thekhyberfebruary-2013/the-pashtunistan-concept-does-ithave-wider-support-in-pakhtunkhwa/

Khan, S. (2012). Effects of Terrorism on Tourism Industry. Mansehra: Department of Tourism and Hospitality in the Hazara University.
Khanzada, A. A. (2016, July 01). 'KP belongs to Afghans' statement taken out of context: Achakzai. Retrieved June 30, 2017, from DAWN: https://www.dawn.com/news/1268402

Khattak, A. (2011, August 09). ANP Demands One More Province For Pashtuns of Balochistan. Retrieved from Siasat: https://www.siasat.pk/forum/showthread.php?7 5588-ANP-demands-one-more-province-forPashtuns-of-Balochistan

Lakiwal. (n.d.). Pashtun Districts of Balochistan. Retrieved June 26, 2017, from Khyber Watch: http://www.khyberwatch.com/forums/showthre ad.php?7204-Pashtun-districts-of-balochistan

Lin, B. (2017). Pakistan: Conflict profile. Retrieved July 01, 2017, from Peace Direct: https://www.insightonconflict.org/conflicts/paki stan/conflict-profile/

Markey, D. S. (2016, May 12). Behind China's Gambit in Pakistan. Retrieved from Council on Foriegn Relations: https://www.cfr.org/expertbrief/behind-chinas-gambit-pakistan

Mirza, Z. (2009, December 27). We were planning to break Pakistan when Benazir died: Zulfikar Mirza. Retrieved June 28, 2017, from Living In Pakistan: https://livinginpakistan.wordpress.com/2009/12 /27/we-were-planning-to-break-pakistan-whenbenazir-died-zulfikar-mirza/

Nayani, A. (2017). The State's Role in Pakistan's Ethnic Violence. Retrieved June 30, 2017, from The World Post: http://www.huffingtonpost.com/aziznayani/the-states-role-in-pakist_b_2809184.html

PBS. (2019). Population by Province / Region Since 1951. Retrieved from Pakistan Bureau of Statistics: https://www.pbs.gov.pk/content/populationprovince-region-1951

Percentage Distribution of Households by Language Usually Spoken and Region/Province (1998 Census). (n.d.). Retrieved June 26, 2017, from http://www.pbs.gov.pk/sites/default/files/other /yearbook2011/Population/16-20.pdf

Rehman, T. (2017, 07 26). Language and Identity in Pakistan. Retrieved from Slide Player: http://slideplayer.com/slide/10888132/

Rolls, M. (2008). Will Devolution Improves the Accountability and Responsiveness of Social Service Delivery in Balochistan, Pakistan? A Political 
Economy Perspective. London: Developmental Studies Institute at LSE.

Sangi, S. (2014, December 04). Analysis: Sindhi nationalists stand divided. Retrieved June 29, 2017, from

DAWN: https://www.dawn.com/news/1148698

Shahid, S. (2002, March 23). Gwadar project launched: Musharraf lauds China's assistance. Retrieved June 30, 2017, from DAWN: https://www.dawn.com/news/27285

Singh, J. S. (2010). Religion and the History of Sikhs. Amritsar: Printwell. Retrieved from American Punjabi

News:
http://americanpunjabinews.com/files/Chapter8.pdf

The News. (September 13, 2013). Retrieved from The News:

https://www.thenews.com.pk/archive/amp/454 532-pti-demands-new-provinces-onadministrative-basis

Veena, Y. (2015, December 05). How Balochistan became a part of Pakistan - a historical perspective. Retrieved from The Nation: https://nation.com.pk/05-Dec-2015/howbalochistan-became-a-part-of-pakistan-ahistorical-perspective.

Publisher's note: EScience Press remains neutral with regard to jurisdictional claims in published maps and institutional affiliations.

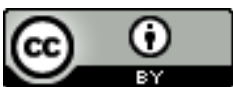

Open Access This article is licensed under a Creative Commons Attribution 4.0 International License, which permits use, sharing, adaptation, distribution and reproduction in any medium or format, as long as you give appropriate credit to the original author(s) and the source, provide a link to the Creative Commons license and indicate if changes were made. The images or other third-party material in this article are included in the article's Creative Commons license, unless indicated otherwise in a credit line to the material. If material is not included in the article's Creative Commons license and your intended use is not permitted by statutory regulation or exceeds the permitted use, you will need to obtain permission directly from the copyright holder. To view a copy of this license, visit http://creativecommons.org/licenses/by/4.0/.

(C) The Author(s) 2021. 